Int. J. Dev. Biol. 63: 321-331 (2019)

https://doi.org/10.1387/ijdb.190128sb

\title{
The past, present and future of Dictyostelium as a model system
}

\author{
SALVATORE BOZZARO* \\ Department of Clinical and Biological Sciences, University of Turin, AOU S. Luigi, Torino, Italy
}

\begin{abstract}
The social amoeba Dictyostelium discoideum has been a preferred model organism during the last $\mathbf{5 0}$ years, particularly for the study of cell motility and chemotaxis, phagocytosis and macropinocytosis, intercellular adhesion, pattern formation, caspase-independent cell death and more recently autophagy and social evolution. Being a soil amoeba and professional phagocyte, thus exposed to a variety of potential pathogens, D. discoideum has also proven to be a powerful genetic and cellular model for investigating host-pathogen interactions and microbial infections. The finding that the Dictyostelium genome harbours several homologs of human genes responsible for a variety of diseases has stimulated their analysis, providing new insights into the mechanism of action of the encoded proteins and in some cases into the defect underlying the disease. Recent technological developments have covered the genetic gap between mammals and non-mammalian model organisms, challenging the modelling role of the latter. Is there a future for Dictyostelium discoideum as a model organism?
\end{abstract}

KEY WORDS: Dictyostelium, chemotaxis, phagocytosis, host-pathogen interaction, cell adhesion

\section{Introduction}

The selective use of organisms other than humans has been very critical in biology and medicine for centuries, mostly due to practical reasons that made convenient to study complex biological phenomena in simple species. The emergence of some of these species as "model organisms" has been a recent development, which took place concomitantly with advancement in genome sequencing, leading to a sort of official recognition by the $\mathrm{NIH}$. To quote from the $\mathrm{NIH}$ internet site: "Model organisms are a small group of research organisms that serve as a proxy for understanding the biology of humans.. Many aspects of these organisms' biology are similar to ours, and much is already known about their genetic makeup. For these and other reasons, studying model organisms helps scientists learn more about human health".

As evident from this statement, the model organisms, whatever their evolutionary distance from humans, are functional to the understanding of human biology, leading eventually to knowledge that is relevant for human health. Obviously any organism, which has been selected over the years as object of investigation by a scientific tribe, is an intra-species or intra-genus organism of reference, such as Saccharomyces cerevisiae for yeasts, Drosophila melanogaster for insects, Arabidopsis Thaliana for plants or Dic- tyostelium discoideum for the amoebozoa, but these organisms have reached the model status because they were amenable, more than other organisms, to genetic and molecular analysis of some processes that are relevant for all organisms, including humans. For that reason, if the concept of model organism is clear, the life of a model organism, its emergence, establishment or passing away is fluid and can be favoured or endangered by many factors, such as new technological developments, new biological questions or their re-shaping, and last but not least the emergence of new unforeseen competitors.

\section{Peculiarities and advantages of Dictyostelium discoideum as model organism}

Among the non-mammalian model organisms, Dictyostelium discoideum (in the following Dictyostelium) is unique, due to cell division and development being totally uncoupled, and because of the transition from a unicellular to a multicellular stage during the life cycle. Growing cells proliferate by binary fission but do not differentiate, whereas starving cells undergo multicellular development and differentiation without dividing and without any need for external nutrients. Thus growth and development can be studied separately, and several non-lethal mutants can be isolated

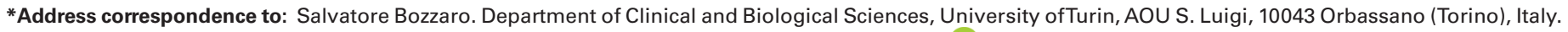
E-mail: salvatore.bozzaro@unito.it - web: https://www.dscb.unito.it/do/gruppi.pl/Show?_id=rq0i - iD https://orcid.org/0000-0001-6323-6190
}

Supplementary Material (one movie) for this paper is available at: https://doi.org/10.1387/ijdb.190128sb

Submitted: 31 May, 2019. Accepted: 11 June, 2019

ISSN: Online 1696-3547, Print 0214-6282

(C) 2019 UPV/EHU Press

Printed in Spain 

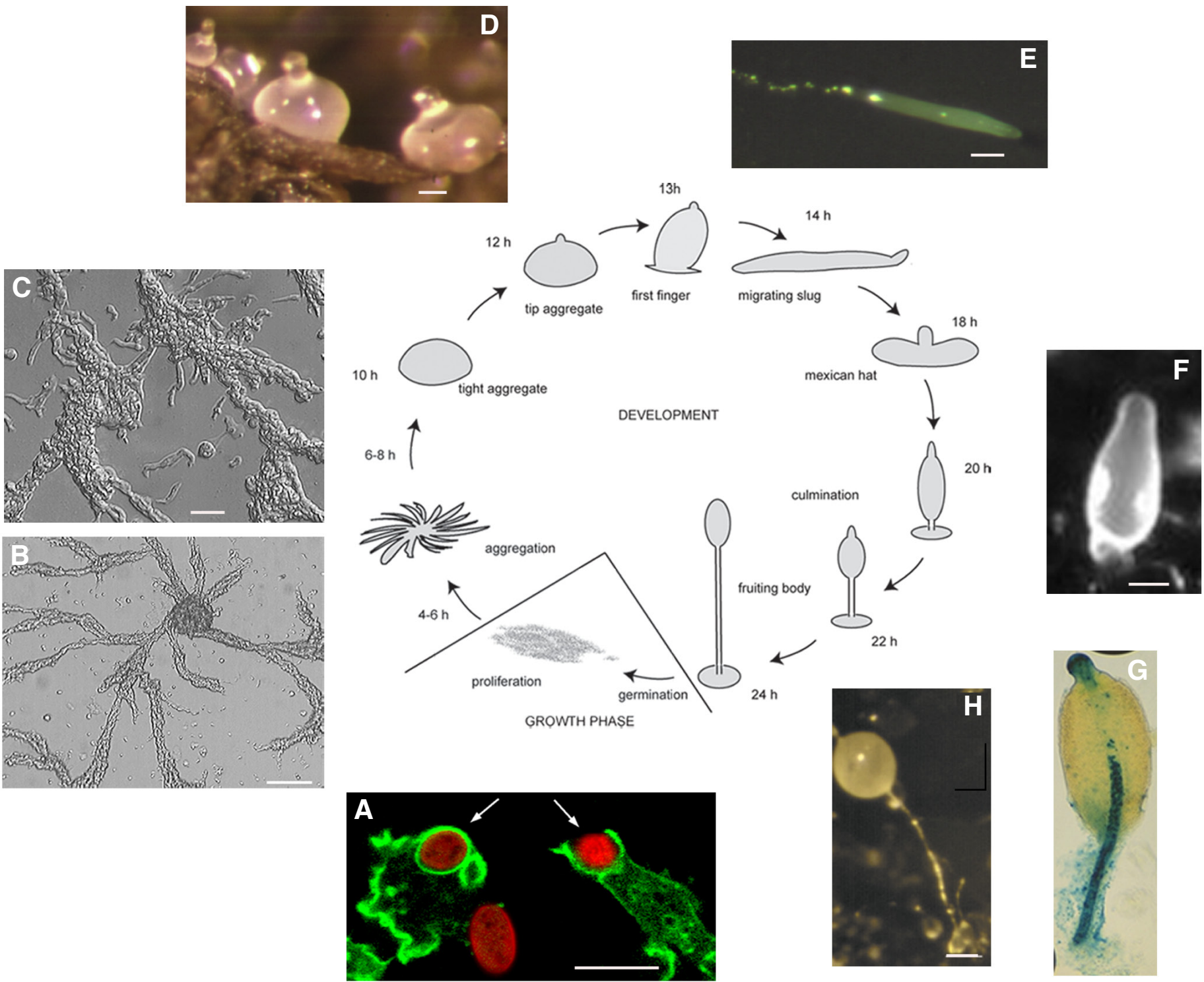

Fig. 1. The life cycle of Dictyostelium discoideum. The different stages of growth and development on non-nutrient agar plate with approximate timing are shown clockwise. (A) Growth-phase cells expressing actin-GFP (green) engulfing yeast particles (red) in a phagocytic cup or a phagosome (Bar: $0.01 \mathrm{~mm})$. (B,C) During aggregation, chemoattractant cyclic AMP relay leads to cell streaming towards aggregation centers. Chemotacting cells are elongated and adhere strongly to each other by end-to-end and lateral contacts (B: $0.1 \mathrm{~mm} ; \mathrm{C}: 0.001 \mathrm{~mm}$ ). (D) Tight aggregates (mounds) form a tip on top of the mound. Cell differentiation into pre-stalk and pre-spore cells in the mounds leads to preferential pre-stalk cell sorting in the tip, which is the source of CAMP that leads to mound elongation into first finger and slug. The tipped aggregates and the slugs are coated with an extracellular matrix secreted by the cells (Bar: $0.1 \mathrm{~mm})$. (E) The slugs undergo migration toward light sources and regions of lower humidity, shedding behind cells and extracellular matrix (Bar: $0.1 \mathrm{~mm}$ ). (F-H) Upper light favours culmination, leading to formation first of a mexican hat and then of a culminating slug, with the pre-stalk cells moving inward the culminating fruiting body and differentiating into vacuolized stalk cells, that give rise to the stalk of the mature fruiting body, whereas the pre-spore cells accumulate in the sorus, differentiating into mature spores. In (G) pre-stalk cells expressing beta-galactosidase (blue) are shown in the stalk and the tip of the culminating slug (Bar: $0.1 \mathrm{~mm}$ ). See also Movie in Supplementary Material for aggregation, and text for additional details.

that are affected in some aspects of development, while growing perfectly well.

Wild type Dictyostelium cells are soil amoebae, living in forest detritus in association with a large variety of bacteria, strictly depending on them for growth (Kessin, 2001). The cells are very efficient phagocytes, and being exposed to potential pathogens, they have developed defence mechanisms that are shared in large part with macrophages. Thus, Dictyostelium has been one of the established and preferred model organisms for studying phagocytosis and host-pathogen interactions (Bozzaro et al., 2008). In recent years, symbiotic forms of interactions with some bacteria strains, which are carried by the cells during development as a sort of rudimentary farming, have also been described (Brock et al., 2011). In contrast to bacteria, no reports exist on Dictyostelium wild type isolates carrying viruses, though it is possible that they might be infected by some giant viruses, as it has been shown for 
other amoebae (Colson et al., 2017).

Lab strains able to grow axenically in a mixture of peptone and yeast extract, but also in defined minimal media, were selected already in the " 70 s of the last century, and since then they have been very useful for classical and molecular genetic studies. Their ability to grow axenically is linked to deletion of a few genes, particularly the one encoding the putative RasGAP NF1 (Bloomfield et al., 2015), which results in fluid-phase uptake by macropinocytosis, a process that is very inefficient, if not absent, in the parental wild type isolates.

During growth and the initial stage of development up to formation of aggregates, the Dictyostelium colony is a population of single amoeboid cells that are capable of actively moving over solid substrata. Development is triggered by starvation and results in cells acquiring the ability to gather together into aggregates, by secreting and responding chemotactically to cyclic AMP, and to stably adhere to each other by tissue-like adhesive bonds (Fig. 1 and Supplementary Movie 1). Several thousands of cells in each aggregate cooperate in constructing a migrating "slug", whereby the individual amoebae become integrated into a unitary sausageshaped organism coated by a secreted extracellular matrix (Fig. 1). The slugs migrate over the substratum towards light and along temperature gradients. Like animal embryos, each slug has an embryonic organizer - the anterior tip - that regulates collective behaviour, pattern formation, cell fate as well as final morphogenesis (Chisholm and Firtel, 2004, Kessin, 2001). Roughly $80 \%$ of the cells in the culminating slug differentiate into spores, whereas the remaining $20 \%$ become stalk cells, i.e. highly vacuolized dead cells that form the stalk of the mature fruiting body (Fig. 1). This complex life cycle highlights the uniqueness and the advantages of Dictyostelium as a model organism:

(1) The variety of cellular and developmental processes that can be easily studied in Dictyostelium is manifold, and a wide range of biochemical and cell biological assays have been devised over the years, including assays in cell motility and chemotaxis, macropinocytosis, phagocytosis and host-pathogen interactions, cell-cell and cell-substratum adhesion, resistance to osmotic stress, single cell differentiation, caspase-independent cell death and autophagy (Eichinger and Rivero, 2006, 2013), just to mention a few.

(2) Essential for a model organism, Dictyostelium cells exhibit rapid growth ( 3 to 8 hours duplication time, when cultured on bacteria or in axenic culture media, respectively), rapid development (24 hours), small size of mature organisms (micrometer range), making possible to work with statistically high number of cells and organisms. Large yields of cells with defined identity can be easily cultured, facilitating biochemical studies. Growth and development occur optimally at temperatures between 20 and $23^{\circ} \mathrm{C}$, under atmospheric $\mathrm{CO}_{2}$ levels, development can be induced by just washing the growing cells in a simple salt solution, and all stages of development can be easily followed on agar or on filter paper and, at least up to tight aggregate formation, even on a glass slide.

(3) Dictyostelium cells were among the first eukaryotic cells in which in vivo imaging of fluorescent protein chimeras was applied, both at the level of single cells and three-dimensional organism (Gerisch et al., 1995, Müller-Taubenberger, 2006), and they are amenable to any kind of imaging microscopy techniques. More importantly, for ease of genetic manipulation Dictyostelium is probably surpassed only by the yeast, though Dictyostelium differs from yeast in many respects, particularly regarding motility and multicellular development. A powerful collection of forward- and reverse-genetic tools has been worked out to manipulate genes (Eichinger and Rivero, 2006). Until recently, only axenic strains were amenable to molecular genetic treatments, but protocols are now available to efficiently transfect and manipulate wild type strains growing on bacteria (Paschke et al., 2018).

Dictyostelium is haploid, therefore gene disruption by homologous recombination usually causes phenotypes without the need for further manipulation. Multiple knockout mutants can be created by Cre/LoxP-mediated recombination (Faix et al., 2004, Linkner et al., 2012), thus facilitating analysis of gene families or gene networks. Recombination or para-sexual complementation is possible only with a few selected strains (Bloomfield et al., 2019), but mutants may be generally rescued by introducing the gene of interest in wild type or mutated form. In addition to its use for disrupting genes by homologous recombination, restriction enzyme mediated integration (REMI) has been used for suppression genetics (Shaulsky et al., 1996).

Recently, a Genome Wide Dictyostelium Insertion (GWDI) project based on REMI-seq technology has led to the establishment of a collection of 5.705 single knockout mutants, covering $42 \%$ of all annotated genes (https://remi-seq.org/). Libraries and handling protocols for analysing these mutants are available in the Dicty stock center (www.dictybase.org), which also offers a wide selection of plasmids, mutants and stable cell lines with ablated or overexpressed genes. A cDNA library representing 55\% of all genes expressed at different developmental stages is also available (Urushihara et al., 2006). Novel genetic tools, such as Crispr/ Cas9-mediated genome editing, have been recently shown to be applicable to Dictyostelium cells (Muramoto et al., 2019).

(4) Critical for successful model organism research is the establishment and maintenance of infrastructures enabling crossdisciplinary communication and exchange of materials, including stock/strain centers and databases for rapid communication of research. As just mentioned, a centralized Dicty stock/strain center was established already 30 years ago, together with a community resource database (www.dictybase.org), where curated and annotated gene models as well as standardized research techniques, a comprehensive reference library and several genetic tools can be browsed.

\section{Past and present of a model organism}

As mentioned in the introduction, a lower organism has been considered valuable as model in so far as it is possible to study at molecular and genetic level, thus "modeling", a relevant biological process otherwise difficult to tackle in mammals or humans. The identification of homologous, and even more, orthologous genes products with similar biochemical and molecular function between a lower model organism and mammals, has strengthened this role. We will see in the last section that recent technological developments are challenging the role of lower model organisms. However, before dealing with this question, it is worth mentioning what has been the contribution of Dictyostelium as a model organism, and which processes have been successfully modelled so far in this organism. This was the subject of a detailed review published a few years ago (Bozzaro, 2013), which the reader is referred to. In this short report I will only summarize the major topics and mention some relevant papers or reviews that have been published in the 
last 6 years after that review (Table 1).

Dictyostelium has been and still is a leading model for eukaryotic chemotaxis (Devreotes and Horwitz, 2015), and one of the established models for other motility-linked processes, such as cytokinesis (Srivastava et al., 2016), phagocytosis (Bozzaro et al., 2008), macropinocytosis and endo-lysosomal traffic (Williams and Kay, 2018); (Williams et al., 2019). Concerning cell motility, an uninterrupted series of studies in the last 50 years has led to the identification and characterization of the acto-myosin cytoskeleton underlying changes in cell shape and cell motility processes, with many cytoskeletal proteins first identified and/or characterized in Dictyostelium, such as coronin, the actin nucleator SCAR, the 34-kDa actin-crosslinking protein, myosin I and II, and formins (see Bozzaro, 2013 for references). The dynamic structure of the cell cortex, the actin cytoskeleton-nuclear membrane interactions, nucleus/nucleolus and the microtubule cytoskeleton, and their regulation by small GTPases have been the subject of several studies also in recent years (Nichols et al., 2015; Gräf et al., 2015; Rivero and Xiong, 2016; Meyer et al., 2017; Pitzen et al., 2018). Recently, the role of formins in regulating the functional integrity of the cell cortex has been investigated in detail (Junemann et al., 2016), and it has been shown that the HSBP1 protein, which regulates WASH complex assembly at centrosomes, is required for development of focal adhesion and cell polarity in Dictyostelium as well as in tumour cells (Visweshwaran et al., 2018). Arginylation, a post-translational modification regulated by the conserved enzyme arginyl-tRNA-protein (Ate1), has been shown to control actin polymerization, affecting focal adhesion and motility (Batsios et al., 2019). Evidence has also been provided that microtubules control mitochondria fission, fusion and motility (Woods et al., 2016).

The dynamics of chemotaxis and its regulatory pathways have continued to be the subject of intense studies in Dictyostelium, in particular for understanding how the different signalling networks are wired together, and for generating models of random and oriented cell motility in 2- and 3-D, often anticipating results and insights that have promoted research in neutrophils and other organisms (Stuelten et al., 2018; van Haastert et al., 2018; Liu et al., 2018; Li et al., 2018; Nichols et al., 2015; Edwards et al., 2018).

Among recent contributions, it is worth mentioning that chemotactic signal relay has been shown to be mediated by released exosomes, containing adenylyl cyclase and cAMP, the latter being secreted via an ABC transporter (Kriebel et al., 2018). Extracellular vesicles as a form of detoxifying mechanism had been already described in Dictyostelium long ago (Tatischeff, 2019, Tatischeff et al., 1998), and this latter result confirms that they can act as potential carrier of biological information.

A phospho-proteomic approach has led to the identification of the atypical ERK2 kinase as a sort of master regulator of the signalling network that drives chemotaxis (Nichols et al., 2019). ERK2 knockout abolishes folate and cAMP chemotaxis, confirming its essential role in controlling chemotaxis (Schwebs et al., 2018).

Sensitivity to chemoattractants appears to be negatively and positively controlled by PKA, HECT ubiquitin ligase-dependent ubiquitination and a novel negative regulator of Ras signalling (Scavello et al., 2017; Pergolizzi et al., 2017; Xu et al., 2017), whereas stochastic as well as chemotactically oriented pseudopod formation could be driven by a coupled excitable Ras/PI(3-4)P2/F actin system (van Haastert et al., 2017; Li et al., 2018).

A structural study of the $\mathrm{G}$ protein interacting protein 1 (Gip1) has revealed how Gip1 binds and sequesters the heterotrimeric $G$ protein, regulating $\mathrm{G}$ protein-coupled receptor signalling in chemotaxis (Miyagawa et al., 2018). The same group has also elegantly shown that the heterotrimeric $\mathrm{G}$ protein dynamics is able to adapt to different concentrations of CAMP, explaining chemotaxis over a wider concentration range of the chemoattractant (Miyanaga et al., 2018).

Research with Dictyostelium cells was very influential in the '70' 80 of the last century for establishing that intercellular adhesion was mediated by specific membrane proteins, against the at that time prevailing view that cell adhesion simply depended on the sum of attractive and repulsive forces operating at the cell surface, irrespective of specific "adhesion molecules", whose search for was considered irrelevant. The successful immunological strategy developed with Dictyostelium cells for the identification of the contact sites A and B (csA and csB) (Beug et al., 1973; Gerisch, 1980 ), was soon adopted in mammals, leading to the identification of N-CAM (Brackenbury et al., 1977) and the first cadherin (uvomorulin, later called cadherin E) (Hyafill et al., 1980). The finding a few years later that disruption of the gene encoding the homophylic adhesion glycoprotein csA, though being essential for EDTA-stable adhesion during the aggregation stage, failed to affect development (Noegel et al., 1985), represented a temporary drawback, overcome when it was shown that the apparent redundancy was due to the standard laboratory conditions not being as stringent as those in the natural environment (Ponte et al., 1998). This led indirectly to the csA encoding gene being recognized as the first "greenbeard" gene, promoting research of greenbeard genes involved in kin discrimination in other organisms (Queller et al., 2003; Gardner and West, 2010; Gruenheit et al., 2017; Strassmann, 2016; (Heller et al., 2016).

TABLE 1

\section{BIOLOGICAL PROCESSES SUCCESSFULLY MODELLED IN DICTYOSTELIUM}

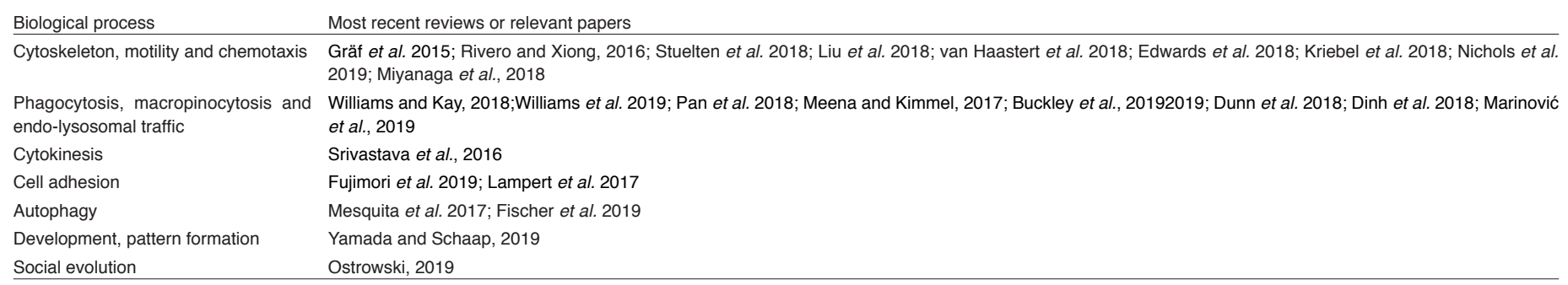


The immunological approach led also to identification of a 150 kDa glycoprotein, encoded by the lagC1 gene, mediating heterophylic adhesion at the postaggregative stage (Geltosky et al., 1979). Later it was shown that the LagC1 and LagB1 glycoproteins (now called TgrB1 and TgrC1) mediated heterophylic adhesion and were responsible for differential adhesiveness between prespore and prestalk cells at the slug stage (Benabentos et al., 2009, Hirose et al., 2017). Recently, it has been elegantly shown that this form of adhesion cooperates, in a cell-type specific manner, with cAMPdriven chemotaxis in mediating $3-D$ cell migration and cell sorting, thus pattern formation, during slug morphogenesis (Fujimori et al., 2019). It is likely that this result will have an impact in mammalian cell sorting out studies.

Dictyostelium cells are very suited to biophysical studies of cellcell and cell-substratum adhesion, as shown by several reports in the past and in recent years (Kamprad et al., 2018; Lampert et al., 2017; Zhu et al., 2015; Tarantola et al., 2014; Wang et al., 2014; Schindl et al., 1995; Helenius et al., 2018; Heinrich et al., 2015).

Although it was well known that Dictyostelium cells grow by ingesting bacteria, systematic studies on the molecular basis of phagocytosis and macropinocytosis started relatively late, namely in the ' 90 s of the last century, almost concomitantly with investigations on host-pathogen interactions. Since then, these lines of research have been vigorously pursued by several labs, firmly establishing Dictyostelium as a model for professional phagocytosis, macropinocytosis and as model host for an increasing number of clinically relevant bacterial pathogens. Dictyostelium cells have been used for in vivo imaging of the dynamics of phagocytosis, macropinocytosis and infection, exploiting the large collection of cytoskeletal or intracellular traffic proteins fused to fluorescent reporters. Genetic studies involving knockout mutants, unbiased mutational screens, genome-wide transcriptional changes and proteomic analysis during phagocytosis, macropinocytosis or infection have produced a large wealth of data, which have been the subject of several reviews in the last years (Bozzaro and Eichinger, 2011; Dunn et al., 2018; Cardenal-Muñoz et al., 2018; Swart et al., 2018). Among more recent data not yet covered by reviews, it is worth mentioning: (I) evidence that Dictyostelium cells are highly sensitive to bacterial chemoattractants, but phagocytosis per se is independent of chemoreceptor sensing (Meena and Kimmel, 2017); (II) in apparent contrast to this, the characterization of the G protein-coupled, folic acid receptor fAR1, which recognizes the saccharide core of LPS and stimulates gram-negative bacterial phagocytosis, providing a plausible mechanism for the involvement of $\mathrm{G}$ proteins in phagocytosis (Pan et al., 2018); discrepancy between both results may be due to the different phagocytosis assays used; (III) evidence that Dictyostelium discriminates between Gram-(-) and Gram-(+) bacteria, migrating preferentially toward Gram-(-) bacteria (Rashidi and Ostrowski, 2019), and that their growth on Gram-(-) or Gram$(+)$ bacteria elicit different transcriptomic profiles, with some genes essential for growth (Nasser et al., 2013); ((IV) the identification of PIKFyve/FAB1 in controlling acidification of phagosomes (Buckley et al., 2019), thus extending previous studies on the role of phosphoinositides in phagocytosis, macropinocytosis and resistance to pathogens (Swart et al., 2018; Hoeller et al., 2013; Peracino et al., 2010; (V) Similarly, it has been shown that the RasGAP lqgC is a negative regulator of macropinocytosis and large particle phagocytosis (Marinović et al., 2019), strengthening the role of Ras signalling in these processes (Williams et al., 2019; Junemann et al., 2016; Bolourani et al., 2010; (VI) While bacterial phagocytosis is essential for growth, it has also been shown that during slug stage, cells maintain as endosymbionts bacteria that have been coated with the secreted lectin discoidin I, and that could possibly be used later as a food source (Dinh et al., 2018).

Concerning host-pathogen interactions, zinc poisoning, in addition to iron restriction, has been further investigated in Dictyostelium interactions with Legionella pneumophila, Mycobacterium marinum or Escherichia coli (Buracco et al., 2018; Barisch et al., 2018), whereas it has been definitely shown that the orthologous iron transporter Nramp1 induces iron efflux from the phagosome (Buracco et al., 2015), and acts as resistance factor, in addition to Legionella and mycobacteria, also against Francisella infection (Brenz et al., 2017). Evidence has also been provided that the ESCRT machinery and autophagy cooperate in controlling mycobacteria infection (López-Jiménez etal., 2018), and that saposin-like proteins, which are encoded by several genes in Dictyostelium, do have amoebapore-like activity (Dhakshinamoorthy et al., 2018).

Detailed investigations with Legionella pneumophila during the last 15 years have shown that intracellular growth of the pathogen needs structurally functional actin cytoskeleton, endoplasmic reticulum, mitochondria and the endo-lysosomal traffic machinery. In contrast, regulatory factors of endo-lysosomal vesicle traffic and fusion, of iron transport in endo-lysosomal vesicles and of the stress response hinder Legionella growth and, if not already compromised as in the knockout mutants, are possibly tagged by Legionella (Bozzaro and Eichinger, 2011; Steiner et al., 2018; Steinert, 2011). Similarly to Legionella, regulation of phosphoinositide pattern in the replicating vacuole by phosphatases controls replication of Mycobacterium marinum in Dictyostelium and macrophages (Koliwer-Brandl et al., 2019). In addition to Legionella and mycobacteria, which have been much studied in their interactions with Dictyostelium, investigations with Salmonella enterica serovar Thyphimurium and Klebsiella pneumoniae have led to the identification of different traits as virulence factors (Varas et al., 2018); (Marcoleta et al., 2018). In summary, Dictyostelium has proven to be a powerful model for investigating host-pathogen interactions and microbial infections. The easy generation and analysis of mutants will strengthen its role as a model system complementary to mammalian macrophages, particularly for dissecting the host response and for integrating this response with the pathogeninduced changes in the replicative vacuole.

Studies on autophagy and apoptosis-independent cell death started with a pioneering paper in 2003 (Otto et al., 2003), and in the last 15 years have shed light on the mechanisms that regulate autophagosome formation (Mesquita et al., 2017), and on the involvement of autophagy in defence against bacterial infections (López-Jiménez et al., 2018), in development and cell differentiation (Fischer et al., 2019; Yamada and Schaap, 2019).

Dictyostelium has also emerged in the last years as a powerful simple model for genetic analysis of social evolution (Ostrowski, 2019), a topic that is covered in this issue by the review of J. Strassman, which the reader is referred to.

\section{Dictyostelium as a model for biomedical research: recent contributions}

The occurrence in the Dictyostelium genome of several genes homologous to disease genes in humans has stimulated the use 
of Dictyostelium as model for dissecting the biological function of these genes and the mechanism of action of the encoded proteins. Dictyostelium cells have also been very useful as test-bed for pharmacogenetic studies. In the previous review (Bozzaro, 2013) and in a collection of dedicated papers (Escalante, 2011), these topics were covered in detail (see also Table 2), thus I will only mention major publications published in the last six years.

The finding that mitochondrial respiratory deficiencies induce in Dictyostelium a consistent pattern of altered phenotypes has been further exploited to investigate genes involved in mitochondrial diseases (Annesley et al., 2014). It has been shown that mutations in the Dictyostelium homologues of two Parkinson's disease associated proteins, DJ-1 and HTRA2, have differential effects on mitochondrial dysfunction (Chen et al., 2018; Chen et al., 2017).

Several papers have studied genes whose variants are involved in the neuronal ceroid lipofuscinosis (NCL) Batten disease. Knockdown or knockout of proteins, such as TPP1 (Tripeptidyl peptidase), CIn3 or CIn5, affected Dictyostelium cell growth and development. Interestingly, CIn3 disruption triggers TPP1 as well as CIn5 up-regulation, providing evidence for molecular networking of NCL proteins (Smith et al., 2019; Huber and Mathavarajah, 2018; McLaren et al., 2019; Phillips and Gomer, 2015; Huber et al., 2014). Cln5 has been also shown to be secreted and to act as glycoside hydrolase both in Dictyostelium and in human cells. Potential interactors have also been identified (Huber and Mathavarajah, 2018). Among these interactors is the Golgi $\mathrm{pH}$ regulator (GPHR) protein, which binds to TPP1 via domains that are also present in the mammalian proteins. Whether this interaction is important for the disease is open (Stumpf et al., 2017).

Dictyostelium Roco4 kinase had been successfully used as model to study the structural and biochemical characteristics of the human LRRK2 kinase, whose mutations are the most frequent cause of dominant inherited Parkinson disease (Gilsbach et al., 2012). The same authors have then characterized the structure of two inhibitors bound to mutated Roco4, showing that this system can be used for optimizing LRR2K inhibitors (Gilsbach et al., 2015). Based on these studies, a new model of LRKK2 activation has been recently proposed (Wauters et al., 2019).

It was already known that Dictyostelium cells are quite resistant to protein misfolding and aggregation, a hallmark of several neurodegenerative diseases (Santarriaga et al., 2015; Malinovska et al., 2015). Recent work has allowed to identifying the serine-rich chaperone protein 1 (SRCP1) as a molecular chaperone necessary and sufficient in Dictyostelium to suppress poly- $Q$ expanded protein aggregation, leading to their degradation in proteasomes (Santarriaga et al., 2018).

The potential of Dictyostelium cells for drug screening and pharmacogenetic studies had been illustrated in the past with studies with aminobisphosphonate, cisplatin, valproic acid and lithium (Alexander et al., 2013; Otto et al., 2016). These studies have now been extended to the characterization of curcumin and naringenin, which were found to inhibit development and/or growth (Cocorocchio et al., 2018; Swatson et al., 2017; Garige and Walters, 2015; Waheed et al., 2014).

The polyketide Differentiation Inducing Factors (DIFs) 1-3, which are produced by Dictyostelium cells and induce stalk cell differentiation (Masento et al., 1988), and several of their synthetic derivatives have been shown to have not only anti-tumoral (Arioka et al., 2017; Dubois et al., 2016; Kubokura et al., 2015; TakahashiYanaga et al., 2014), but also anti-microbial activities, interestingly against Gram-positive, but not Gram-negative, bacteria (Kubohara et al., 2019), suggesting that Dictyostelium can be an important source in drug discovery (Kubohara and Kikuchi, 2018).

\section{Is there a future for Dictyostelium as a model organism?}

From this very short survey it is evident that Dictyostelium has been so far a very useful model organism, in particular for unravelling cell biological processes. It is likely that many of the research lines outlined above will be pursued also in the near future.

The utility of non-mammalian model organisms for the understanding of human biology, and ultimately human diseases, however, has been questioned in the last years due to impressive technological progress that has made possible studying mammals to an extent unforeseen a few years ago. In addition to the huge array of biochemical and molecular biology tools, tailored for research with mammalian and human cells, genome-wide association studies and whole genome sequencing has facilitated the direct discovery of disease genes and variants in humans. New genetic tools, such as CRISPR/Cas9, have made mammalian and human cells accessible to genetic manipulation and editing, reducing the genetic gap with lower model organisms. Furthermore, disease modelling can be done with increasing effectiveness using human induced pluripotent stem cells or 3-D organoids (Wang et al., 2019; Chen and Knoepfler 2016; Robbins and Price, 2017; Dutta et al., 2017; Ortiz-Vitali and Darabi, 2019). In view of these developments, and in consideration of the increased competitiveness and pressure for research funding, it is difficult to anticipate what could be the future of Dictyostelium as a model organism.

There are, clearly, some limitations that make studies with lower organisms still unavoidable (Rine, 2014). Human disease phenotypes in many cases do not provide clues about the underlying molecular defect, thus unbiased genetic experiments in experimentally tractable organisms are required to establish

TABLE 2

\section{HUMAN DISEASES AND BIOMEDICAL RESEARCH STUDIES MODELLED IN DICTYOSTELIUM}

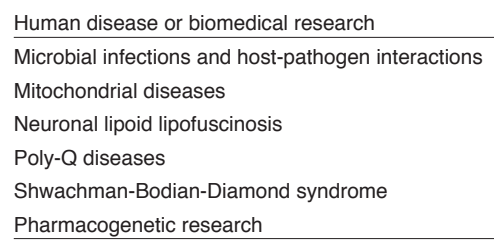

Only selected reviews and/or papers published after 2013 are listed. For additional references see text. 
causal mechanisms of gene action (Aitman et al., 2011). Emblematically, evidence that the SBDS (Shwachman-Bodian-Diamond syndrome) protein, whose mutations cause bone marrow failure and leukemia in humans, is required for translational activation of ribosomes, thus that SBDS is a ribosomopathy, was not originated from observation or analysis of the disease phenotypes, but from unbiased studies first in yeast and then in Dictyostelium (Menne et al., 2007; Wong et al., 2011; Weis et al., 2015). This case shows that lower organisms are better suited than mammals or human cell lines for large scale and straightforward genetic analysis of pathophysiological mechanisms, and as such they are an important filter for an ethically responsible and better designed use of mammals, thus implementing the so-called 3-Rs policy, namely Refinement of experimental design, Reduction of experiments with mammals, Replacement with other techniques.

It is increasingly evident that biochemical and molecular function of a given protein are generally conserved among different organisms. The "organismal"-level phenotypes, however, may be different in different species, even for conserved genes. Thus, PKA or GSK are kinases in all organisms, but their disruption affects chemotaxis and development in Dictyostelium, nutrient and stress signalling in yeast, neuronal plasticity and neurodegenerative disorders, among a plethora of other phenotypes, in mammals. The emergence of different phenotypes is a consequence of the fact that the relationships between genes and phenotypes are manifold, but this obviousness underlines a major role of model organisms. Besides helping understanding the biological mechanism or function of a given gene, a model organism is important because it helps integrating genes in gene networks, and gene networks in biological contexts i.e. phenotypes, which are species-specific but in some way equivalent between different model organisms, though their recognition is not immediate. Unraveling the complexity of biologi- cal processes behind the simpler phenotypes of lower organisms eventually helps their translation to mammalian and human biology. This may lead to a better understanding of human diseases as a consequence. From this point of view, it is worthwhile to remind a few aspects that make attractive Dictyostelium:

(1) This organism integrates at the level of the same cell a large variety of cellular processes that can be used as readouts of gene functions (during growth: mitosis and cytokinesis, macropinocytosis, phagocytosis, host-pathogen interactions, cell motility and chemotaxis toward bacteria, cell-substratum adhesion; upon starvation: chemotaxis driven by cAMP signalling, cell polarization, cell-cell and cell-substratum adhesion, cell streaming and cellular oscillations; in the multicellular stage: cell differentiation into a few cell lineages (pre-spore cells, pre-stalk cells, anterior-like cells, sentinel cells) coupled with pattern formation and morphogenesis (3-D cell migration, phototaxis and cell sorting within the slug and the culminating fruiting body). Inactivating or overexpressing one or more genes can affect any one of these "phenotypes", thus favouring a systematic analysis of genes and their encoded proteins;

(2) Dictyostelium offers the opportunity for a comprehensive understanding of the biological principles regulating each one of the processes listed above at the level of a whole organism, which will still be very difficult in future with mammals. Dictyostelium shares this opportunity with yeast, but the variety of biological processes that can be modelled in Dictyostelium is much larger than in yeast. Most of the 13.000 genes in the Dictyostelium genome are now annotated with functional information in the Dictyostelium genome database, and more than 5.000 single mutants with known gene disruption are now available. By analysing these mutants and generating epistatic gene interactions, coupled with "omics" technologies, Dictyostelium researchers are in a position to unravel the pathways involved in each one of the processes mentioned

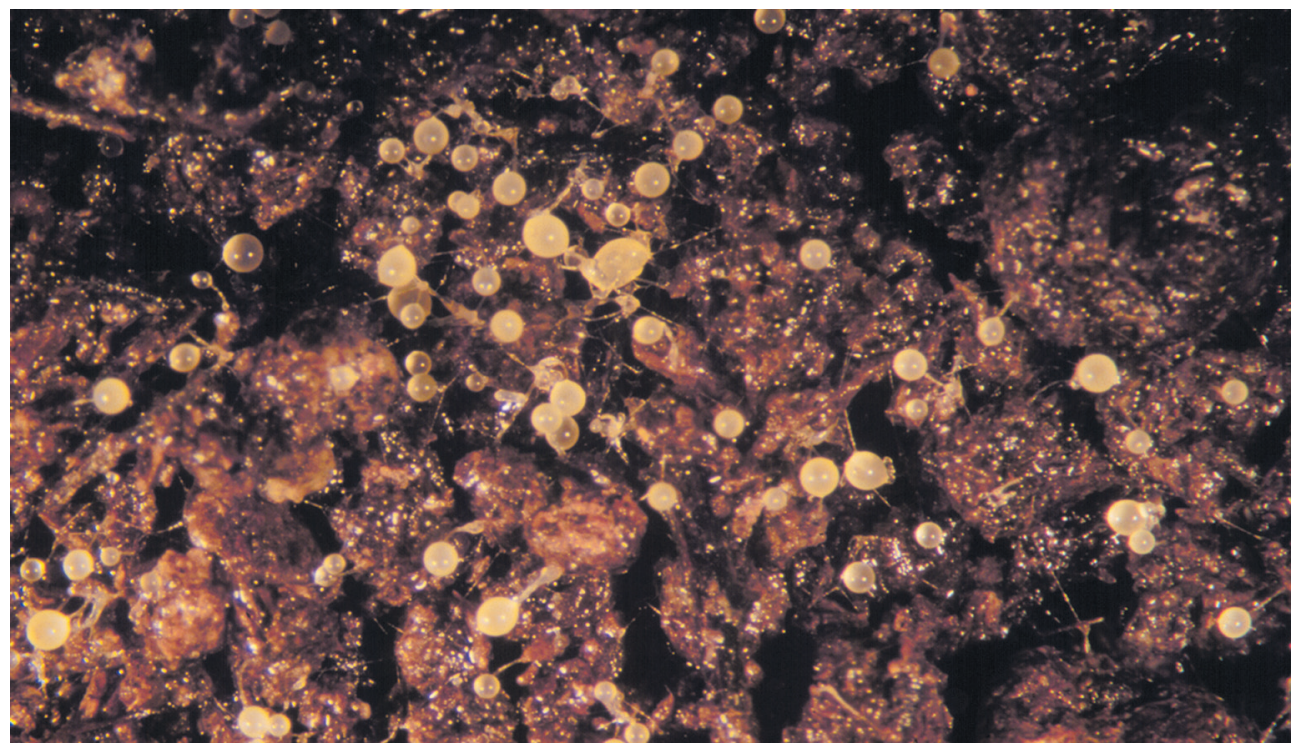

Fig. 2. Dictyostelium fruiting bodies formed on garden soil. Under standard laboratory conditions, Dictyostelium development is studied on nonnutrient agar plates. The smooth, hydrophilic agar surface is highly artificial compared to the forest soil where Dictyostelium cells normally live. It is possible to reproduce in the lab conditions which are closer to the natural ones, by using commercially available garden soil, eventually of different texture (sandy, loamy or clay) and with different degrees of moisture. The surface of any garden soil is rough, much less uniform than agar, with "mountains and valleys" that cells have to overcome for undergoing first aggregation and then slug migration. Under these more stringent conditions it is possible to detect phenotypes of mutants, compared to parental cells, which are otherwise undetectable on agar, thus facilitating the study of the effects on development of prima facie "redundant" genes (see Ponte et al., 1998, 2000). 
above and how they are wired together.

(3) Experiments in Dictyostelium, as well as other organisms including mammals, are usually conducted under defined laboratory conditions, which are not the environment in which they have evolved. This has led to apparentredundancy in many experimental systems, i.e. disruption of presumably functional genes with no obvious phenotype (Rine, 2014). It has been shown that it is possible for Dictyostelium to reproduce in the lab conditions that are closer to the environmental ones (Fig. 2), thus revealing phenotypes of disrupted genes that were not detectable under standard laboratory conditions (Ponte et al., 2000, 1998). This opportunity should be exploited in future in a more systematic way, provided now the large library of mutants available.

(4) Acritical mass of investigators working on the same organism and sharing common tools and resources is required for model organism research to maintain the infrastructures required by the community and to survive in the highly competitive field. The Dictyostelium community is relatively small, compared e.g. to the yeast or Drosophilacommunity. This could be a serious handicap in future, but also an opportunity for young talented scientists that will recognize and exploit the potentialities of what can be considered a "model organism for all seasons", while avoiding overcrowded fields of research.

\section{References}

AITMAN, T., BOONE, C., CHURCHILL, G., HENGARTNER, M., MACKAY, T. and STEMPLE, D. (2011). The future of model organisms in human disease research. Nat Rev Genet 12: 575-582.

ALEXANDER, S., SWATSON, W.S. and ALEXANDER, H. (2013). Pharmacogenetics of resistance to Cisplatin and other anticancer drugs and the role of sphingolipid metabolism. Methods Mol Biol 983: 185-204.

ANNESLEY, S.J., CHEN, S., FRANCIONE, L.M., SANISLAV, O., CHAVAN, A.J., FARAH, C., DE PIAZZA, S.W., STOREY, C.L., ILIEVSKA, J., FERNANDO, S.G. et al., (2014). Dictyostelium, a microbial model for brain disease. Biochim Biophys Acta 1840: 1413-32.

ARIOKA, M., TAKAHASHI-YANAGA, F., KUBO, M., IGAWA, K., TOMOOKA, K. and SASAGURI, T. (2017). Anti-tumor effects of differentiation-inducing factor-1 in malignant melanoma: GSK-3-mediated inhibition of cell proliferation and GSK3 -independent suppression of cell migration and invasion. Biochem Pharmacol 138: 31-48.

BARISCH, C., KALININA, V., LEFRANÇOIS, L., APPIAH, J., LÓPEZ-JIMÉNEZ, A. and SOLDATI, T. (2018). Localization of all four ZnT zinc transporters in Dictyostelium and impact of ZntA and ZntB knockout on bacteria killing. J Cell Sci 131: jcs222000.

BATSIOS, P., ISHIKAWA-ANKERHOLD, H., ROTH, H., SCHLEICHER, M., WONG, C. and MÜLLER-TAUBENBERGER, A. (2019). Ate1-mediated posttranslational arginylation affects substrate adhesion and cell migration in Dictyostelium discoideum. Mol Biol Cell 30: 453-456.

BENABENTOS, R., HIROSE, S., SUCGANG, R., CURK, T., KATOH, M., OSTROWSKI, E.A., STRASSMANN, J.E., QUELLER, D.C., ZUPAN, B., SHAULSKY, G. et al., (2009). Polymorphic members of the lag gene family mediate kin discrimination in Dictyostelium. Curr Biol 19: 567-572.

BEUG, H., KATZ, F.E. and GERISCH, G. (1973). Dynamics in antigenic membrane sites relating to cell aggregation in Dictyostelium discoideum. J. Cell Biol. 56: 647-658.

BLOOMFIELD, G., PASCHKE, P., OKAMOTO, M., STEVENS, T. and URUSHIHARA, H. (2019). Triparental inheritance in Dictyostelium. Proc Natl Acad Sci USA 116: 2187-2192.

BLOOMFIELD, G., TRAYNOR, D., SANDER, S.P., VELTMAN, D.M., PACHEBAT, J.A. and KAY, R.R. (2015). Neurofibromin controls macropinocytosis and phagocytosis in Dictyostelium. Elife 4: e04940.

BOLOURANI, P., SPIEGELMAN, G. and WEEKS, G. (2010). Ras proteins have multiple functions in vegetative cells of Dictyostelium. Eukaryot Cell 9: 1728-33.

BOZZARO, S. (2013). The model organism Dictyostelium discoideum. Methods Mol
Biol 983: 17-37.

BOZZARO, S., BUCCI, C. and STEINERT, M. (2008). Phagocytosis and hostpathogen interactions in Dictyostelium with a look at macrophages. Int Rev Cell Mol Biol 271: 253-300.

BOZZARO, S. and EICHINGER, L. (2011). The professional phagocyte Dictyostelium discoideum as a model host for bacterial pathogens. Curr Drug Targets 12:942-54.

BRACKENBURY, R., THIÉRY, J., RUTISHAUSER, U. and EDELMAN, G. (1977) Adhesion among neural cells of the chick embryo. J Biol Chem 252: 6385-6840.

BRENZ, Y., OHNEZEIT, D., WINTHER-LARSEN, H.Ù. and HAGEDORN, M. (2017). Nramp1 and NrampB Contribute to Resistance against Francisella in Dictyostelium. Front Cell Infect Microbiol 7: 282.

BROCK, D.A., DOUGLAS, T.E., QUELLER, D.C. and STRASSMANN, J.E. (2011). Primitive agriculture in a social amoeba. Nature 469: 393-396.

BUCKLEY, C., HEATH, V., GUÉHO, A., BOSMANI, C., KNOBLOCH, P., SIKAKANA, P., PERSONNIC, N., DOVE, S., MICHELL, R., MEIER, R. etal., (2019). PIKfyve/Fab1 is required for efficient V-ATPase and hydrolase delivery to phagosomes, phagosomal killing, and restriction of Legionella infection. PLOS Pathog 15: e1007551.

BURACCO, S., PERACINO, B., ANDREINI, C., BRACCO, E. and BOZZARO, S. (2018). Differential effects of iron, zinc, and copper on Dictyostelium discoideum cell growth and resistance to Legionella pneumophila. Front Cell Infect Microbio/7:536.

BURACCO, S., PERACINO, B., CINQUETTI, R., SIGNORETTO, E., VOLLERO, A., IMPERIALI, F., CASTAGNA, M., BOSSI, E. and BOZZARO, S. (2015). Dictyostelium Nramp1, which is structurally and functionally similar to mammalian DMT1 transporter, mediates phagosomal iron efflux. J Cell Sci 128: 3304-3316.

CARDENAL-MUÑOZ, E., BARISCH, C., LEFRANÇOIS, L., LÓPEZ-JIMÉNEZ, A. and SOLDATI, T. (2018). When Dicty Met Myco, a (not so) romantic story about one amoeba and its intracellular pathogen. Front Cell Infect Microbiol 7: 529.

CHEN, K. and KNOEPFLER, P. (2016). To CRISPR and beyond: the evolution of genome editing in stem cells. Regen Med 11: 801-816.

CHEN, S., ANNESLEY, S., JASIM, R., MUSCO, V., SANISLAV, O. and FISHER, P. (2017). The Parkinson's disease-associated protein DJ-1 plays a positive nonmitochondrial role in endocytosis in Dictyostelium cells. Dis Model Mech 10: 1261-1271.

CHEN, S., SANISLAV, O., ANNESLEY, S. and FISHER, P. (2018). Mitochondrial HTRA2 plays a positive, protective role in Dictyostelium discoideum but is cytotoxic when overexpressed. Genes 9: e355.

CHISHOLM, R.L. and FIRTEL, R.A. (2004). Insights into morphogenesis from a simple developmental system. Nature Rev. Mol. Cell Biol. 5: 531-541.

COCOROCCHIO, M., AJ.;, B., STEWART, B., KIM, L., HARWOOD, A., THOMPSON, C., ANDREWS, P. and WILLIAMS, R. (2018). Curcumin and derivatives function through protein phosphatase $2 \mathrm{~A}$ and presenilin orthologues in Dictyostelium discoideum. Dis Model Mech 11: dmm032375.

COLSON, P., LASCOLA, B. and RAOULT, D. (2017). Giant viruses of amoebae: a journey through innovative research and paradigm changes. Annu Rev Virol 4: 61-85.

DEVREOTES, P. and HORWITZ, A.R. (2015). Signaling networks that regulate cell migration. Cold Spring Harb Perspect Biol 7: a005959.

DHAKSHINAMOORTHY, R., BITZHENNER, M., COSSON, P., SOLDATIT and LEIPPE, M. (2018). The Saposin-Like Protein ApID Displays Pore-Forming Activity and Participates in Defense Against Bacterial Infection During a Multicellular Stage of Dictyostelium discoideum. Front Cell Infect Microbiol 8: 73.

DINH, C., FARINHOLT, T., HIROSE, S., ZHUCHENKO, O. and KUSPA, A. (2018). Lectins modulate the microbiota of social amoebae. Science 361: 402-406.

DUBOIS, A., GINET, C., FURSTOSS, N., BELAID, A., HAMOUDA, M., ELMANAA, W., CLUZEAU, T., MARCHETTI, S., RICCI, J., JACQUEL, A. et al., (2016). Differentiation inducing factor 3 mediates its anti-leukemic effect through ROS-dependent DRP1-mediated mitochondrial fission and induction of caspase-independent cell death. Oncotarget 7: 26120-26136.

DUNN, J., BOSMANI, C., BARISCH, C., RAYKOV, L., LEFRANÇOIS, L., CARDENALMUÑOZ, E., LÓPEZ-JIMÉNEZ, A. and SOLDATI, T. (2018). Eat Prey, Live: Dictyostelium discoideum As a Model for Cell-Autonomous Defenses. Front Immunol 8: 1906.

DUTTA, D., HEO, I. and CLEVERS, H. (2017). Disease modeling in Stem Cell-derived 3D organoids. Trend Mol Med 23: 393-410

EDWARDS, M., CAI, H., ABUBAKER-SHARIF, B., LONG, Y., LAMPERT, T. and DEVREOTES, P. (2018). Insight from the maximal activation of the signal transduction excitable network in Dictyostelium discoideum. Proc Natl Acad Sci USA 
115: E3722-3730

EICHINGER, L. and RIVERO, F. (2006). Dictyostelium discoideum Protocols. Humana Press, Totowa, NJ.

FAIX, J., KREPPEL, L., SHAULSKY, G., SCHLEICHER, M. and KIMMEL, A.R. (2004). A rapid and efficient method to generate multiple gene disruptions in Dictyostelium discoideum using a single selectable marker and the Cre-loxP system. Nucl. Acids Res. 32: E143.

FISCHER, S., RIJAL, R., FROMMOLT, P., WAGLE, P., KONERTZ, R., J.;, F., MESSLIN, S. and EICHINGER, L. (2019). Functional characterization of ubiquitin-like core autophagy protein ATG12 in Dictyostelium discoideum. Cells 8: e72.

FUJIMORI, T., NAKAJIMA, A., SHIMADA, N. and SAWAI, S. (2019). Tissue selforganization based on collective cell migration by contact activation of locomotion and chemotaxis. Proc Natl Acad Sci USA 116: 4291-4296.

GARDNER, A. and WEST, S. (2010). Greenbeards. Evolution 64: 25-38.

GARIGE, M. and WALTERS, E. (2015). Curcumin inhibits development and cell adhesion in Dictyostelium discoideum: Implications for YakA signaling and GST enzyme function. Biochem Biophys Res Commun 467: 275-81.

GELTOSKY, J.E., WESEMAN, J., BAKKE, A. and LERNER, R.A. (1979). Identification of a cell surface glycoprotein involved in cell aggregation in D. discoideum. Cell 18: 391-398

GERISCH, G. (1980). Univalent antibody fragments as tools for the analysis of cell interactions in Dictyostelium. In Current Topics in Developmental Biology., (ed. FRIEDLANDER, M.). Ac. Press, New York, pp.243-270.

GERISCH, G., ALBRECHT, R., HEIZER, C., HODGKINSON, S. and MANIAK, M. (1995). Chemoattractant-controlled accumulation of coronin at the leading edge of Dictyostelium cells monitored using green fluorescent protein-coronin fusion protein. Curr. Biol. 5: 1280-1285.

GILSBACH, B.K., HO, F.Y., VETTER, I.R., VAN HAASTERT, P.J., WITTINGHOFER, A. and KORTHOLT, A. (2012). Roco kinase structures give insights into the mechanism of Parkinson disease-related leucine-rich-repeat kinase 2 mutations. Proc Natl Acad Sci USA 109: 10322-10327

GILSBACH, B.K., MESSIAS, A.C., ITO, G., SATTLER, M., ALESSI, D.R., WITTINGHOFER, A. and KORTHOLT, A. (2015). Structural Characterization of LRRK2 Inhibitors. J Med Chem 58: 3751-3756.

GRÄF, R., BATSIOS, P. and MEYER, I. (2015). Evolution of centrosomes and the nuclear lamina: Amoebozoan assets. Eur J Cell Biol 94: 249-56.

GRUENHEIT, N., PARKINSON, K., STEWART, B., HOWIE, J., WOLF, J. and THOMPSON, C. (2017). A polychromatic 'greenbeard' locus determines patterns of cooperation in a social amoeba. Nature Commun 8: 1-9.

HEINRICH, D., ECKE, M., JASNIN, M., ENGEL, U. and GERISCH, G. (2015). Reversible membrane pearling in live cells upon destrcution of the actin cortex. Biophys j 106: 1079-1091.

HELENIUS, J., ECKE, M., MÜLLER, D. and GERISCH, G. (2018). Oscillatory Switches of Dorso-Ventral Polarity in Cells Confined between Two Surfaces. Biophys j 115: 150-162.

HELLER, J., ZHAO, J., ROSENFIELD, G., KOWBEL, D., GLADIEUX, P. and GLASS, N. (2016). Characterization of greenbeard genes involved in long-distance kind discrimination in a microbial eukaryote. PLoS Biol 14: e1002431.

HIROSE, S., CHEN, G., KUSPA, A. and SHAULSKY, G. (2017). The polymorphic proteins TgrB1 and TgrC1 function as a ligand-receptor pair in Dictyostelium allorecognition. J Cell Sci 130: 4002-4012.

HOELLER, O., BOlOURANI, P., CLARK, J., STEPHENS, L.R., HAWKINS, P.T., WEINER, O.D., WEEKS, G. and KAY, R.R. (2013). Two distinct functions for PI3-kinases in macropinocytosis. J Cell Sci 126: 4296-307.

HUBER, R. and MATHAVARAJAH, S. (2018). Secretion and function of Cln5 during the early stages of Dictyostelium development. Biochim Biophys Acta Mol Cell Res 1865: 1437-1450.

HUBER, R.J., MYRE, M.A. and COTMAN, S.L. (2014). Loss of Cln3 function in the social amoeba Dictyostelium discoideum causes pleiotropic effects that are rescued by human CLN3. PLoS One 9: e110544.

HYAFILL, F., MORELLO, D., BABINET.C and JACOB, F. (1980). A cell surface glycoprotein involved in the compaction of embryonal carcinoma cells and cleavage stage embryos. Cell 21: 927-934.

JUNEMANN, A., FILIĆ, V., WINTERHOFF, M., NORDHOLZ, B., LITSCHKO, C., SCHWELLENBACH, H., STEPHAN, T., WEBER, I. and FAIX, J. (2016). A
Diaphanous-related formin links Ras signaling directly to actin assembly in macropinocytosis and phagocytosis. Proc Natl Acad Sci USA 113: E7464-E7472.

KAMPRAD, N., WITT, H., SCHRÖDER, M., KREIS, C., BÄUMCHEN, O., JANSHOFF, A. and TARANTOLA, M. (2018). Adhesion strategies of Dictyostelium discoideuma force spectroscopy study. Nanoscale 10: 22504-22519.

KESSIN, R.H. (2001). Dictyostelium - Evolution, cell biology, and the development of multicellularity. Cambridge Univ. Press, Cambridge, UK.

KOLIWER-BRANDL, H., P.;, K., BARISCH, C., WELIN, A., HANNA, N., SOLDATI, T. and HILBI, H. (2019). Distinct Mycobacterium marinum phosphatases determine pathogen vacuole phosphoinositide pattern, phagosome maturation, and escape to the cytosol. Cell Microbiol 21: 313008.

KRIEBEL, P., MAJUMDAR, R., JENKINS, L., SENOO, H., WANG, W., AMMU, S., CHE, N.S., NARAYAN, K., IIJIMA, M. and PARENT, C. (2018). Extracellular vesicles direct migration by synthesizing and releasing chemotactic signals. $J$ Cell Biol 217: 2891-2910.

KUBOHARA, Y. and KIKUCHI, H. (2018). Dictyostelium: an important source of structural and functional diversity in drug discovery. Cells 8: E6.

KUBOHARA, Y., SHIRATSUCHI, Y., ISHIGAKI, H., TAKAHASHI, K., OSHIMA, Y and KIKUCHI, H. (2019). Antimicrobial Activities of Dictyostelium DifferentiationInducing Factors and Their Derivatives. Biomolecules 9: E163.

KUBOKURA, N., TAKAHASHI-YANAGA, F., ARIOKA, M., YOSHIHARA, T., IGAWA K., TOMOOKA, K., MORIMOTO, S., NAKATSU, Y., TSUZUKI, T., NAKABEPPU, $Y$. et al., (2015). Differentiation-inducing factor-3 inhibits intestinal tumor growth in vitro and in vivo. J Pharmacol Sci 127: 446-55.

LAMPERT, T., KAMPRAD, N., EDWARDS, M., BORLEIS, J., WATSON, A., TARANTOLA, M. and DEVREOTES, P. (2017). Shear force-based genetic screen reveals negative regulators of cell adhesion and protrusive activity. Proc Natl Acad Sci USA 114: E7727-E7736.

LI, X., EDWARDS, M., SWANEY, K., SINGH, N., BHATTACHARYA, S., BORLEIS, J., LONG, Y., IGLESIAS, P., CHEN, J. and DEVREOTES, P. (2018). Mutually inhibitory Ras-PI(3,4)P2 feedback loops mediate cell migration. Proc Natl Acad USA 115: E9125-E9134

LINKNER, J., NORDHOLZ, B., JUNEMANN, A., WINTERHOFF, M. and FAIX, J (2012). Highly effective removal of floxed Blasticidin $S$ resistance cassettes from Dictyostelium discoideum mutants by extrachromosomal expression of Cre. Eur J Cell Biol 91: 156-60.

LIU, Y., LACAL, J., FIRTEL, R. and KORTHOLT, A. (2018). Connecting G protein signaling to chemoattractant-mediated cell polarity and cytoskeletal reorganization. Small GTPases 9: 360-364.

LÓPEZ-JIMÉNEZ, A., CARDENAL-MUÑOZ, E., LEUBA, F., GERSTENMAIER, L., BARISCH, C., HAGEDORN, M., KING, J. and SOLDATI, T. (2018). The ESCRT and autophagy machineries cooperate to repair ESX-1-dependent damage at the Mycobacterium-containing vacuole but have opposite impact on containing the infection. PLoS Pathog 14.

MALINOVSKA, L. and ALBERTI, S. (2015). Protein misfolding in Dictyostelium Using a freak of nature to gain insight into a universal problem. Prion 9: 339-46.

MALINOVSKA, L., PALM, S., GIBSON, K., VERBAVATZ, J.M. and ALBERTI, S. (2015) Dictyostelium discoideum has a highly $\mathrm{Q} / \mathrm{N}$-rich proteome and shows an unusua resilience to protein aggregation. Proc Natl Acad Sci USA 112: E2620-E2629.

MARCOLETA, A., VARAS, M., ORTIZ-SEVERÍN, J., VÁSQUEZ, L., BERRÍOSPASTÉN, C., SABAG, A., CHÁVEZ, F., ALLENDE, M., SANTIVIAGO, C., MONASTERIO, O. et al., (2018). Evaluating Different Virulence Traits of Klebsiella pneumoniae Using Dictyostelium discoideum and Zebrafish Larvae as Host Models. Front Cell Infect Microbiol 8: 30.

MARINOVIĆ, M., MIJANOVIĆ, L., ŠOŠTAR, M., VIZOVIŠEK, M., JUNEMANN, A FONOVIĆ, M., TURK, B., WEBER, I., FAIX, J. and FILIĆ, V. (2019). IQGAP-related protein lqgC suppresses Ras signaling during large-scale endocytosis. Proc Nat Acad Sci USA 116: 1289-1298.

MASENTO, M.S., MORRIS, H.R., TAYLOR, G.W., JOHNSON, S.J., SKAPSKI, A.C. and KAY, R.R. (1988). Differentiation-inducing factor from the slime mould Dictyostelium discoideum and its analogues. Synthesis, structure and biological activity. Biochem. J. 256: 23-28.

MCLAREN, M., MATHAVARAJAH, S. and HUBER, R. (2019). Recent Insights into NCL Protein Function Using the Model Organism Dictyostelium discoideum. Cells 8: E115.

MEENA, N. and KIMMEL, A. (2017). Chemotactic network responses to live bacteria 
show independence of phagocytosis from chemoreceptor sensing. Elife 6: e24627.

MENNE, T., GOYENECHEA, B., SÁNCHEZ-PUIG, N., WONG, C., TONKIN, L., ANCLIFF, P., BROST, R., COSTANZO, M., BOONE, C. and WARREN, A. (2007). The Shwachman-Bodian-Diamond syndrome protein mediates translational activation of ribosomes in yeast. Nat Genetics 39: 486-495.

MESQUITA, A., CARDENAL-MUÑOZ, E., DOMINGUEZ, E., MUÑOZ-BRACERAS, S., NUÑEZ-CORCUERA, B., PHILLIPS, B., TÁBARA, L., XIONG, Q., CORIA, R., EICHINGER, L. etal., (2017). Autophagy in Dictyostelium: Mechanisms, regulation and disease in a simple biomedical model. Autophagy 13: 24-40.

MEYER, I., PETER, T., BATSIOS, P., KUHNERT, O., KRÜGER-GENGE,A., CAMURÇA, C. and GRÄF, R. (2017). CP39, CP75 and CP91 are major structural components of the Dictyostelium centrosome's core structure. Eur J Cell Biol 96: 19-130.

MIYAGAWA, T., KOTEISHI, H., KAMIMURA, Y., MIYANAGA, Y., TAKESHITA, K., NAKAGAWA, A. and UEDA, M. (2018). Structural basis of Gip1 for cytosolic sequestration of $G$ protein in wide-range chemotaxis. Nat Commun 9: 4635.

MIYANAGA, Y., KAMIMURA, Y., KUWAYAMA, H., DEVREOTES, P. and UEDA, M. (2018). Chemoattractant receptors activate, recruit and capture $G$ proteins for wide range chemotaxis. Biochem Biophys Res Commun 507: 304-310.

MÜLLER-TAUBENBERGER, A. (2006). Application of fluorescent protein tags as reporters in live-cell imaging studies. Meth. Mol. Biol. 346: 229-246.

MURAMOTO, T., IRIKI, H., WATANABE, J. and KAWATA, T. (2019). Recent advances in CRISPR/Cas9-mediated genome editing in Dictyostelium. Cells 12;8: E46.

NASSER, W., SANTHANAM, B., MIRANDA, E.R., PARIKH, A., JUNEJA, K., ROT, G., DINH, C., CHEN, R., ZUPAN, B., SHAULSKY, G. et al., (2013). Bacterial discrimination by dictyostelid amoebae reveals the complexity of ancient interspecies interactions. Curr Biol 23: 862-72.

NICHOLS, J., PASCHKE, P., PEAK-CHEW, S., WILLIAMS, T., TWEEDY, L., SKEHEL, M., STEPHENS, E., CHUBB, J. and KAY, R. (2019). The Atypical MAP Kinase ErkB Transmits Distinct Chemotactic Signals through a Core Signaling Module. Dev Cell 48: 491-505.e9.

NICHOLS, J.M., VELTMAN, D. and KAY, R.R. (2015). Chemotaxis of a model organism: progress with Dictyostelium. Curr Opin Cell Biol 36: 7-12.

NOEGEL, A., HARLOFF, C., HIRTH, P., MERKL, R., MODERSITZKI, M., STADLER, J., WEINHART, U., WESTPHAL, M. and GERISCH, G. (1985). Probing an adhesion mutant of Dictyostelium discoideum with cDNA clones and monoclonal antibodies indicates a specific defect in the contact site Aglycoprotein. EMBOJ. 4:3805-3810.

ORTIZ-VITALI, J. and DARABI, R. (2019). iPSCs as a Platform for Disease Modeling, Drug Screening, and Personalized Therapy in Muscular Dystrophies. Cells 8: E20.

OSTROWSKI, E. (2019). Enforcing Cooperation in the Social Amoebae. Curr Biol 29: R474-R489.

OTTO, G., COCOROCCHIO, M., MUNOZ, L., TYSON, R., BRETSCHNEIDER, T. and WILLIAMS, R. (2016). Employing Dictyostelium as an advantegeous 3Rs model for pharmagenetics research. Methods Mol Biol 1407: 123-130.

OTTO, G., WU, M., KAZGAN, N.,;, ANDERSON, O.,; and KESSIN, R. (2003). Macroautophagy is required for multicellular development of the social amoeba Dictyostelium discoideum. J. Biol. Chem. 278: 17636-17645.

PAN, M., NEILSON, M., GRUNFELD, A., CRUZ, P., WEN, X., INSALL, R. and JIN, T. (2018). A G-protein-coupled chemoattractant receptor recognizes lipopolysaccharide for bacterial phagocytosis. PLoS Biol 16: e2005754.

PASCHKE, P., KNECHT, D., SILALE, A., TRAYNOR, D., WILLIAMS, T., THOMASON, P., INSALL, R., CHUBB, J., KAY, R. and VELTMAN, D. (2018). Rapid and efficient genetic engineering of both wild type and axenic strains of Dictyostelium discoideum. PLoS One 13: e0196809.

PERACINO, B., BALEST, A. and BOZZARO, S. (2010). Phosphoinositides differentially regulate bacterial uptake and Nramp1-induced resistance to Legionella infection in Dictyostelium. J Cell Sci 123: 4039-51.

PERGOLIZZI, B., BRACCO, E. and BOZZARO S. (2017). A new HECT ubiquitin ligase regulating chemotaxis and development in Dictyostelium discoideum. $J$ Cell Sci 130: 551-562.

PHILLIPS, J.E. and GOMER, R.H. (2015). Partial genetic suppression of a loss-offunction mutant of the neuronal ceroid lipofuscinosis-associated protease TPP1 in Dictyostelium discoideum. Dis Model Mech 8: 147-56.

PITZEN, V., ASKARZADA, S., GRÄF, R. and MEYER, I. (2018). CDK5RAP2 Is an Essential Scaffolding Protein of the Corona of the Dictyostelium Centrosome. Cells 7: E32.
PONTE, E., BRACCO, E., FAIX, J. and BOZZARO, S. (1998). Detection of subtle phenotypes: The case of the cell adhesion molecule csA in Dictyostelium. Proc. Natl. Acad. Sci. USA 95: 9360-9365.

PONTE, E., RIVERO, F., FECHHEIMER, M., NOEGEL, A. and BOZZARO, S. (2000) Severe developmental defects in Dictyostelium null mutants for actin-binding proteins. Mech. Devel. 91: 153-161.

QUELLER, D.C., PONTE, E., BOZZARO, S. and STRASSMANN, J.E. (2003). Single-gene greenbeard effects in the social amoeba Dictyostelium discoideum. Science 299: 105-106.

RASHIDI, G. and OSTROWSKI, E. (2019). Phagocyte chase behaviours: discrimination between Gram-negative and Gram-positive bacteria by amoebae. Biol Lett 15: 20180607

RINE, J. (2014). A future of the model organism. Mol Biol Cell 25: 549-553.

RIVERO, F. and XIONG, H. (2016). Rho signaling in Dictyostelium. Int Rev Cell Mol Biol 322: 61-181.

ROBBINS, J. and PRICE, J. (2017). Human induced pluripotent stem cells as a research tool in Alzheimer's disease. Psychol Med 47: 2587-2592.

SANTARRIAGA, S., HAVER, H., KANACK, A., FIKEJS, A., SISON, S., EGNER, J. BOSTROM, J., SEMINARY, E., HILL, R., LINK, B. et al., (2018). SRCP1 conveys resistance to polyglutamine aggregation. Mol Cell 71: 216-228.e7.

SANTARRIAGA, S., PETERSEN, A., NDUKWE, K., BRANDT, A., GERGES, N. BRUNS SCAGLIONE, J. and SCAGLIONE, K.M. (2015). The Social Amoeba Dictyostelium discoideum Is Highly Resistant to Polyglutamine Aggregation. $J$ Biol Chem 290: 25571-8

SCAVELLO, M., PETLICK, A., RAMESH, R., THOMPSON, V., LOTFI, P. and CHAREST P. (2017). Protein kinase A regulates the Ras, Rap1 and TORC2 pathways in response to the chemoattractant CAMP in Dictyostelium. J Cell Sci 130:1545-1558.

SCHINDL, M., WALLRAFF, E., DEUBZER, B., WITKE, W., GERISCH, G. and SACKMANN, E. (1995). Cell-substrate interactions and locomotion of Dictyostelium wild-type and mutants defective in three cytoskeletal proteins: A study using quantitative reflection interference contrast microscopy. Biophys. J. 68: 1177-1190.

SCHWEBS, D., PAN, M., ADHIKARI, N., KUBURICH, N., JIN, T. and HADWIGER, J. (2018). Dictyostelium Erk2 is an atypical MAPK required for chemotaxis. Cell Signal 27: 147-155.

SHAULSKY, G., ESCALANTE, R. and LOOMIS, W.F. (1996). Developmental signal transduction pathways uncovered by genetic suppressors. Proc. Natl. Acad. Sci. USA 93: 15260-15265.

SMITH, P., SEN, M., FISHER, P. and ANNESLEY, S. (2019). Modelling of Neuronal Ceroid Lipofuscinosis Type 2 in Dictyostelium discoideum Suggests That Cytopathological Outcomes Result from Altered TOR Signalling. Cells 8: E469.

SRIVASTAVA, V., IGLESIAS, P.A. and ROBINSON, D.N. (2016). Cytokinesis: Robust cell shape regulation. Semin Cell Dev Biol 53: 39-44.

STEINER, B., WEBER, S. and HILBI, H. (2018). Formation of the Legionella-containing vacuole: phosphoinositide conversion, GTPase modulation and ER dynamics. Int J Med Microbiol 308: 49-57.

STEINERT, M. (2011). Pathogen-host interactions in Dictyostelium, Legionella, Mycobacterium and other pathogens. Semin Cell Dev Biol 22: 70-76.

STRASSMANN, J.E. (2016). Kin Discrimination in Dictyostelium Social Amoebae. J Eukaryot Microbiol 63: 378-383.

STUELTEN, C., PARENT, C. and MONTELL, D. (2018). Cell motility in cancer invasion and metastasis: insights from simple model organisms. NatRev Cancer 18:296-312.

STUMPF, M., MÜLLER, R., GASSE, B., WEHRSTEDT, R., FEY, P., KAROW, M., EICHINGER, L., GLÖCKNER, G. and NOEGEL, A. (2017). A tripeptidyl peptidase 1 is a binding partner of the Golgi pH regulator (GPHR) in Dictyostelium. Dis Model Mech 10: 897-907.

SWART, A., HARRISON, C., EICHINGER, L., STEINERT, M. and HILBI, H. (2018) Acanthamoeba and Dictyostelium as Cellular Models for Legionella Infection. Front Cell Infect Microbiol 8: 61.

SWATSON, W., KATOH-KURASAWA, M., SHAULSKY, G. and ALEXANDER, S. (2017). Curcumin affects gene expression and reactive oxygen species via a PKA dependent mechanism in Dictyostelium discoideum. PLoS One 12.

TAKAHASHI-YANAGA, F., YOSHIHARA, T., JINGUSHI, K., IGAWA, K., TOMOOKA K., WATANABE, Y., MORIMOTO, S., NAKATSU, Y., TSUZUKI, T., NAKABEPPU, Y. et al., (2014). DIF-1 inhibits tumor growth in vivo reducing phosphorylation of GSK-3beta and expressions of cyclin D1 and TCF7L2 in cancer model mice. 
Biochem Pharmacol 89: 340-8.

TARANTOLA, M., BAE, A., FULLER, D., BODENSCHATZ, E., RAPPEL, W.J. and LOOMIS, W.F. (2014). Cell substratum adhesion during early development of Dictyostelium discoideum. PLoS One 9: e106574.

TATISCHEFF, I. (2019). Dictyostelium: A model for studying the extracellular vesicle messengers involved in human health and disease. Cells 8: E225.

TATISCHEFF, I., BOMSEL, M., DE PAILLERETS, C., DURAND, H., GENY, B., SEGRETAIN, D., TURPIN, E. and ALFSEN, A. (1998). Dictyostelium discoideum cells shed vesicles with associated DNA and vital stain Hoechst 33342. Cell. Mol. Life Sci. 54: 476-487.

URUSHIHARA, H., MORIO, T. and TANAKA, Y. (2006). The cDNA sequencing project. Meth. Mol. Biol. 346: 31-49.

VAN HAASTERT, P., KEIZER-GUNNINK, I. and KORTHOLT, A. (2017). Coupled excitable Ras and F-actin activation mediates spontaneous pseudopod formation and directed cell movement. Mol Biol Cell 28: 922-934.

VAN HAASTERT, P., KEIZER-GUNNINK, I. and KORTHOLT, A. (2018). The cytoskeleton regulates symmetry transitions in moving amoeboid cells. $J$ Cell Sci 131: JCS208892.

VARAS, M., RIQUELME-BARRIOS, S., VALENZUELA, C., MARCOLETA, A., BERRÍOS-PASTÉN, C., SANTIVIAGO, C. and CHÁVEZ, F. (2018). Inorganic polyphosphate is essential for Salmonella Typhimurium virulence and survival in Dictyostelium discoideum. Front Cell Infect Microbiol 8: 8.

VISWESHWARAN, S., THOMASON, P., GUEROIS, R., VACHER, S., DENISOV, E., TASHIREVA, L., LOMAKINA, M., LAZENNEC-SCHURDEVIN, C., LAKISIC, G., LILLA, S. et al., (2018). The trimeric coiled-coil HSBP1 protein promotes WASH complex assembly at centrosomes. EMBO J 37: e97706.

WAHEED, A., LUDTMANN, M.H., PAKES, N., ROBERY, S., KUSPA, A., DINH, C., BAINES, D., WILLIAMS, R.S. and CAREW, M.A. (2014). Naringenin inhibits the growth of Dictyostelium and MDCK-derived cysts in a TRPP2 (polycystin-2)- dependent manner. Br J Pharmacol 171: 2659-2670.

WANG, C., CHOWDHURY, S., DRISCOLL, M., PARENT, C.A., GUPTA, S.K. and LOSERT, W. (2014). The interplay of cell-cell and cell-substrate adhesion in collective cell migration. $J$ R Soc Interface 11: 20140684.

WANG, M., ZHANG, L. and FH.;, G. (2019). Modeling neuropsychiatric disorders using human induced pluripotent stem cells. Protein Cel/ https://doi.org/10.1007/ s13238-019-0638-8.

WAUTERS, L., VERSÉES, W. and KORTHOLT, A. (2019). Roco proteins: GTPases with a baroque structure and mechanism. Int J Mol Sci 20: E147.

WEIS, F., GIUDICE, E., CHURCHER, M., JIN, L., HILCENKO, C., WONG, C.C., TRAYNOR, D., KAY, R.R. and WARREN, A.J. (2015). Mechanism of elF6 release from the nascent $60 S$ ribosomal subunit. Nat Struct Mol Biol 22: 914-919.

WILLIAMS, T. and KAY, R. (2018). The physiological regulation of macropinocytosis during Dictyostelium growth and development. J Cell Sci 131: 1-13.

WILLIAMS, T., PASCHKE, P. and KAY, R. (2019). Function of small GTPases in Dictyostelium macropinocytosis. Philos Trans R Soc Lond B Biol Sci 374: 20180150.

WONG, C.C., TRAYNOR, D., BASSE, N., KAY, R.R. and WARREN, A.J. (2011). Defective ribosome assembly in Shwachman-Diamond syndrome. Blood 118:4305-4312.

WOODS, L., GW.; B. and K.; N. (2016). Microtubules Are Essential for Mitochondrial Dynamics-Fission, Fusion, and Motility-in Dictyostelium discoideum. Front Cell Dev Biol 4: 19

XU, X., WEN, X., VELTMAN, D., KEIZER-GUNNINK, I., POTS, H., KORTHOLT, A. and JIN, T. (2017). GPCR-controlled membrane recruitment of negative regulator C2GAP1 locally inhibits Ras signaling for adaptation and long-range chemotaxis Proc Natl Acad Sci USA 114: E10992-E10101.

YAMADA, Y. and SCHAAP, P. (2019). Cyclic AMP induciton of Dictyostelium prespore gene expression requires autophagy. Dev Biol S0012-1606(19)30028-4.

ZHU, X., BOUFFANAIS, R. and YUE, D.K. (2015). Interplay between motility and cell-substratum adhesion in amoeboid cells. Biomicrofluidics 9: 054112. 


\section{Further Related Reading, published previously in the Int. J. Dev. Biol.}

All in one - integrating cell polarity, meiosis, mitosis and mechanical forces in early oocyte differentiation in vertebrates Yaniv M. Elkouby

Int. J. Dev. Biol. (2017) 61: 179-193

https://doi.org/10.1387/ijdb.170030ye

Trunk neural crest cells: formation, migration and beyond

Guillermo A. Vega-lopez, Santiago Cerrizuela and Manuel J. Aybar

Int. J. Dev. Biol. (2017) 61: 5-15

https://doi.org/10.1387/ijdb.160408gv

A Dictyostelium discoideum: a model system for differentiation and patterning. $\mathrm{R}$ Escalante and $\mathrm{J} \mathrm{J}$ Vicente

Int. J. Dev. Biol. (2000) 44: 819-835

http://www.ijdb.ehu.es/web/paper/11206323

Development at the edge of multi-cellularity: Dictyostelium discoideum.

R R Kay

Int. J. Dev. Biol. (2000) 44: 35-38

http://www.ijdb.ehu.es/web/paper/10761844

Models of biological pattern formation: common mechanism in plant and animal development.

$\mathrm{H}$ Meinhardt

Int. J. Dev. Biol. (1996) 40: 123-134

http://www.ijdb.ehu.es/web/paper/8735921
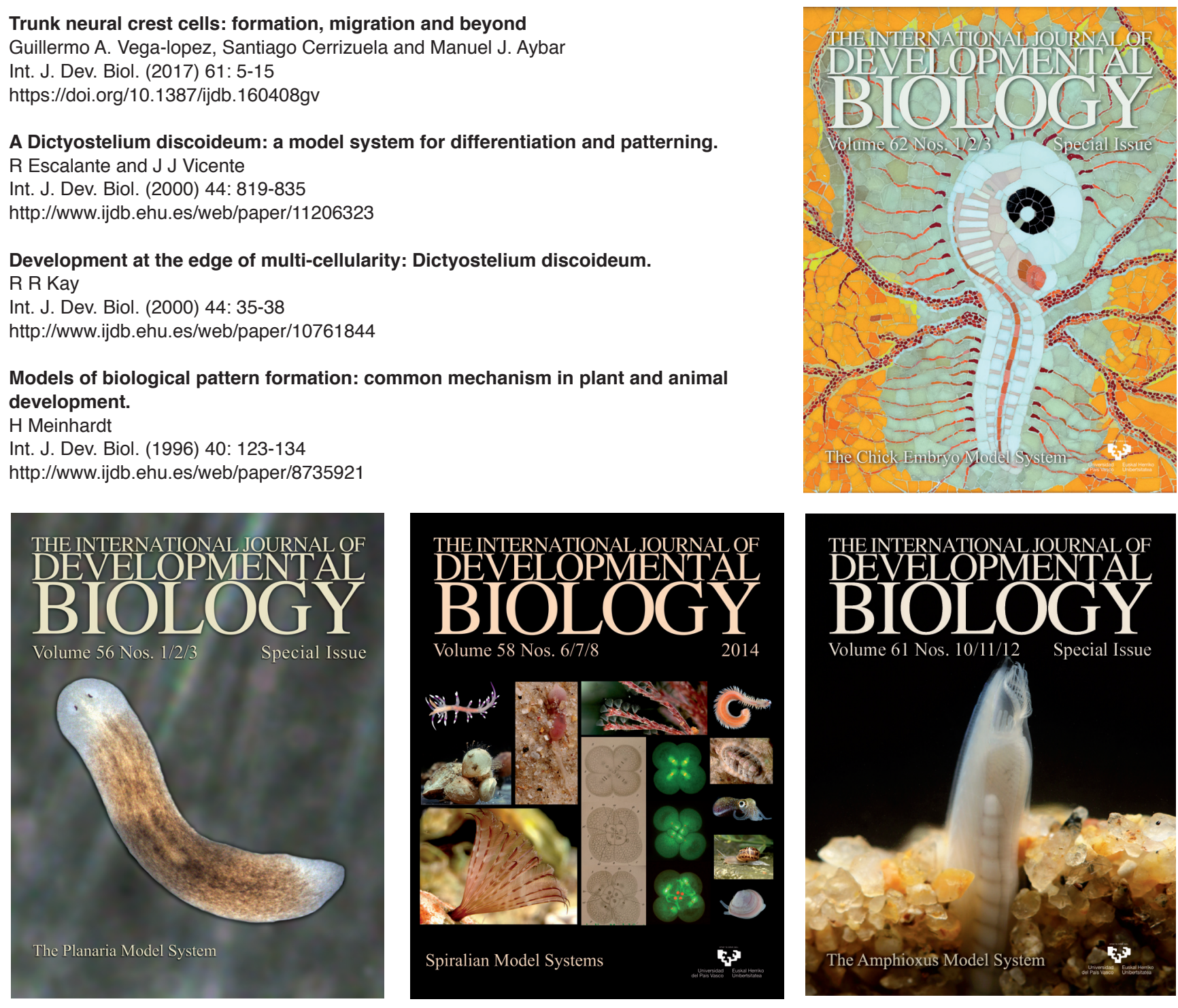